AP05

Callovian to Valanginian Chemostratigraphy of the Eastern Arabian Plate Margin

V. Vahrenkamp* (ADCO) \& A. Al Mansoori (ADCO)

For abstract, PTO

No full paper available 


\title{
15174 Callovian to Valanginian chemostratigraphy of the eastern Arabian Plate margin
}

\author{
Volker C. Vahrenkamp (ADCO <vvahrenkamp@adco.ae>) and Abdulla al Mansoori (ADCO)
}

Following the breakup of Gondwana the northeastern passive margin of the Arabian Plate entered during the Permian a period of long-term thermal subsidence that lasted until renewed tectonic activity in the Early Turonian. This resulted in the more-or-less continuous deposition of mainly carbonate shelf sediments with the section reaching a thickness of up to 4,000 $\mathrm{m}$. A composite carbon-isotope profile for the Callovian to Cenomanian time period has been generated for the eastern Arabian Plate using more than 2,000 carbon-isotope data. The profile has some 1,800 m thickness, is anchored by biostratigraphy, Sr-isotope data and tightly sampled carbon-isotope profiles from various cross-correlated cored wells in the United Arab Emirates and Oman. Further time control is provided by correlation with published curves of carbon-isotope ratio variations through time mainly form the northern Tethys carbonate sequences. A large data set of strontium-isotope data provides absolute time control via correlation with well-dated curves of strontium-isotope ratio variations in seawater over time.

The Callovian to Valanginian interval covers some $900 \mathrm{~m}$ of section. The carbon-isotope signal contains two intervals with obvious overprinting by diagenesis based on $\delta^{13} \mathrm{C}$ ratios $<0.0 \%$. The first is the major Late Tithonian unconformity separating the Sila Group from the Thamama Group. The second are the Mid- to Late Berriasian dolomitic sequences of the Habshan Formation. This overprinting occurs in several wells at the same intervals and is hence considered to reflect overprints caused by regional diagenetic events. However, the rest of the data fall in the range expected for carbonates derived from seawater and show no obvious signs of alteration of their carbon-isotopic composition by subsequent diagenesis. A comparison with published profiles of $\delta^{13} \mathrm{C}$ ratios of seawater over time shows very good correspondence of trends. In particular, recognized are: (1) a significant positive carbon isotope excursion associated with the Oxfordian Hanifa Formation; (2) a positive carbon-isotope excursion in the Lower Berriasian associated with the transgressive deposits of the lower part of the Habshan Formation; and (3) a positive carbon-isotope excursion during the Valanginian (Thamama units F, G and $\mathrm{H}$ ), which likely correlates with the oceanic anoxic event OAE1. 